Article

\title{
Compositional Study and Antioxidant Potential of Ipomoea hederacea Jacq. and Lepidium sativum L. Seeds
}

\author{
Muhammad Zia-Ul-Haq ${ }^{1}$, Shakeel Ahmad ${ }^{2}$, Luca Calani ${ }^{3}$, Teresa Mazzeo ${ }^{3}$, Daniele Del Rio ${ }^{3}$, \\ Nicoletta Pellegrini ${ }^{3}$ and Vincenzo De Feo ${ }^{4, *}$
}

1 Department of Pharmacognosy, Research Institute of Pharmaceutical Sciences, University of Karachi, Karachi-75270, Pakistan; E-Mail: ahirzia@gmail.com

2 Department of Agronomy, Bahauddin Zakariya University, Multan-60800, Pakistan; E-Mail: shakeel.agronomy@gmail.com

3 Department of Public Health, University of Parma, via Volturno 39, 43125 Parma, Italy; E-Mails: luca.calani@nemo.unipr.it (L.C.); mazfer@libero.it (T.M.); daniele.delrio@unipr.it (D.D.R.); nicoletta.pellegrini@unipr.it (N.P.)

4 Department of Pharmaceutical and Biomedical Sciences, Salerno University, Fisciano, 84084 Salerno, Italy; E-Mail: defeo@unisa.it

* Author to whom correspondence should be addressed; E-Mail: defeo@unisa.it; Tel.: +39-089-959-751; Fax: +39-089-969-602.

Received: 8 August 2012; in revised form: 20 August 2012 / Accepted: 21 August 2012 / Published: 29 August 2012

\begin{abstract}
The present investigation has been carried out to determine the proximate composition, amino acids, metal contents, oil composition as well as the antioxidant capacity of the seeds of Ipomoea hederacea Jacq. and Lepidium sativum L. Proximate composition indicated a great difference in oil (14.09 $\pm 0.66,28.03 \pm 1.05)$ and fibre $(16.55 \pm 0.31,6.75 \pm 1.20)$ contents for I. hederacea and L. sativum, respectively. Fatty acid profile indicated that oleic acid $(19.50 \pm 0.37,30.50 \pm 0.16)$ and linoleic acid $(52.09 \pm 0.48,8.60 \pm 0.38)$ are the major fatty acids. $\gamma$-Tocopherol and $\delta$-tocopherol $(28.70 \pm 0.14,111.56 \pm 0.37)$ were the most abundant in the seed oil of $I$. hederacea and L. sativum, respectively. Results of TEAC, FRAP and TRAP antioxidant assays indicated that L. sativum has much greater antioxidant potential than I. hederacea.
\end{abstract}

Keywords: Ipomoea hederacea Jacq.; Lepidium sativum L.; antioxidant capacity; proximate composition 


\section{Introduction}

Lepidium sativum L. (Brassicaceae) is a fast growing annual herb that is native to Egypt and west Asia, although it is now cultivated in the entire World. Its young leaves are eaten raw or cooked, while its seeds are used, fresh or dried, as a seasoning with a peppery flavor [1]. Boiled seeds are consumed in drinks, either ground in honey or as an infusion in hot milk. Its root is used as a condiment while shoots are used in sandwiches [2,3]. The seed paste is applied to rheumatic joints to relieve pain and swelling. The seeds are chewed to treat sore throats, coughs, asthma and headaches, and in large quantities to induce abortion. Seeds pounded in water are used to treat hiccoughs and stomach-aches. The seeds are also considered galactagogue, emmenagogue and laxative and used a dressing for sores on camels and horses [4]. A further use is to prepare a solution to massage infected cows' udders. The seed oil is used as an illuminant and in soap manufacture [5]. Recently, the seed structure of this plant has been reported [6], as well as the seed metabolism during germination [7].

Ipomoea hederacea Jacq. (Convolvulaceae) seeds have diuretic, anthelmintic, and blood purifier properties and are used for treating constipation, dropsy, to produce abortion and promote menstruation. They are laxative, carminative, cure inflammations, abdominal diseases, fevers, headaches and bronchitis. Juice of the leaves is also used for the same purpose. Seeds are useful in skin diseases like leucoderma and scabies, gout, cephalalgia, hepatopathy and splenopathy [8-10].

Antioxidants are an important part of the defense system of the human body and help to cope with oxidative stress caused by reactive oxygen species. Plants are important sources of antioxidants and there is increasing interest in antioxidant analysis of plants. Very little data on compositional studies and the antioxidant potential of these two species exists. As part of our studies to explore the composition and antioxidant potential of the indigenous flora of Pakistan [11-18], this research was carried out to study I. hederacea Jacq. and L. sativum L. seeds for nutritional composition and antioxidant capacity.

\section{Results and Discussion}

The proximate composition of I. hederacea and L. sativum seeds (Table 1) indicates the presence of appreciable amounts of protein $(23.36 \pm 1.02 \%$ to $24.18 \pm 1.54 \%)$, fibre $(16.55 \pm 0.31 \%$ to $6.75 \pm 1.02 \%)$, lipids $(14.09 \pm 0.66 \%$ to $28.03 \pm 1.05 \%)$, ash $(3.65 \pm 1.10 \%$ to $3.92 \pm 1.06 \%)$, moisture $(5.29 \pm 1.02 \%$ to $3.92 \pm 1.06 \%)$ and carbohydrates $(37.06 \pm 0.89 \%$ to $32.87 \pm 0.29 \%)$. Proximate composition varies depending upon plant variety, agronomic practices, stage of collection of seeds and climatic and geological condition of area from where seeds are collected. It is an important indicator and first step during nutritional evaluation of fruits and seeds of plants and crops and it dictates further studies on components which seem more interesting [14,16].

Ash contents indicate the seeds are an appreciable source of minerals. The low moisture content is an index of stability, quality and increased shelf life of seeds [19]. Our results are in partial agreement with those reported earlier for I. hederacea [20,21] and L. sativum [22]. Higher protein and lipid contents indicate that both seeds have high food energy, however seeds cannot be considered safe for consumption since the toxicity levels for the seeds are not established yet. 
Table 1. Proximate chemical composition of seeds (\%).

\begin{tabular}{ccc}
\hline Component & Ipomoea hederacea & Lepidium sativum \\
\hline Crude protein & $23.36 \pm 1.02 \mathrm{~b}$ & $24.18 \pm 1.54 \mathrm{a}$ \\
Total lipids & $14.09 \pm 0.66 \mathrm{~b}$ & $28.03 \pm 1.05 \mathrm{a}$ \\
Total carbohydrates & $37.06 \pm 0.89 \mathrm{a}$ & $32.87 \pm 0.29 \mathrm{~b}$ \\
Crude fiber & $16.55 \pm 0.31 \mathrm{a}$ & $6.75 \pm 1.02 \mathrm{~b}$ \\
Moisture & $5.29 \pm 1.02 \mathrm{a}$ & $3.92 \pm 1.06 \mathrm{~b}$ \\
Ash & $3.65 \pm 1.10 \mathrm{a}$ & $4.25 \pm 0.13 \mathrm{a}$ \\
\hline
\end{tabular}

Data are expressed as the mean \pm standard deviation; values in the same row having different letters differ significantly $(p<0.05)$.

The relatively higher contents of proteins and lipids motivated us to undertake in-depth studies on both types of biomolecules. Data concerning qualitative and quantitative amino acids composition is presented in Table 2. Amino acid composition indicates the nutritional quality of protein. Glutamic acid and aspartic acid were found to be the major non-essential amino acids in the samples tested. Results indicated that all essential amino acids, except S-containing types and tryptophan, are present in high amounts in both species. The amino acid profile showed that methionine and cysteine are present in the lowest concentration. Results are comparable to those of earlier workers for L. sativum $[23,24]$ while there is no previous report on amino acid composition of I. hederacea seeds.

Table 2. Percentage composition of amino acids in seeds.

\begin{tabular}{ccc}
\hline Amino acid & Ipomoea hederacea & Lepidium sativum \\
\hline Isoleucine & $5.03 \pm 0.36 \mathrm{a}$ & $4.19 \pm 0.03 \mathrm{~b}$ \\
Leucine & $6.59 \pm 0.85 \mathrm{~b}$ & $7.03 \pm 0.08 \mathrm{a}$ \\
Lysine & $4.25 \pm 0.54 \mathrm{~b}$ & $5.98 \pm 0.03 \mathrm{a}$ \\
Methionine & $1.17 \pm 0.62 \mathrm{a}$ & $0.51 \pm 0.01 \mathrm{~b}$ \\
Phenylaniline & $6.24 \pm 0.92 \mathrm{a}$ & $5.39 \pm 0.17 \mathrm{~b}$ \\
Threonine & $3.07 \pm 0.31 \mathrm{a}$ & $3.76 \pm 0.08 \mathrm{a}$ \\
Tryptophan & $1.88 \pm 0.05 \mathrm{a}$ & $0.92 \pm 0.07 \mathrm{~b}$ \\
Valine & $7.10 \pm 0.94 \mathrm{a}$ & $6.21 \pm 0.02 \mathrm{~b}$ \\
Arginine & $5.50 \pm 0.23 \mathrm{a}$ & $3.44 \pm 0.11 \mathrm{~b}$ \\
Histidine & $3.55 \pm 0.92 \mathrm{a}$ & $3.87 \pm 0.14 \mathrm{a}$ \\
Alanine & $3.99 \pm 0.37 \mathrm{~b}$ & $4.59 \pm 0.19 \mathrm{a}$ \\
Aspartic acid & $10.82 \pm 0.86 \mathrm{~b}$ & $12.07 \pm 0.31 \mathrm{a}$ \\
Cystine & $0.90 \pm 0.01 \mathrm{a}$ & $0.21 \pm 0.11 \mathrm{a}$ \\
Glutamic acid & $22.71 \pm 0.41 \mathrm{~b}$ & $24.29 \pm 0.75 \mathrm{a}$ \\
Glycine & $5.36 \pm 0.39 \mathrm{a}$ & $5.08 \pm 0.12 \mathrm{a}$ \\
Proline & $4.46 \pm 0.53 \mathrm{a}$ & $4.63 \pm 0.36 \mathrm{a}$ \\
Serine & $4.02 \pm 0.46 \mathrm{a}$ & $4.18 \pm 0.55 \mathrm{a}$ \\
Tyrosine & $2.58 \pm 0.59 \mathrm{a}$ & $2.88 \pm 0.69 \mathrm{a}$ \\
\hline
\end{tabular}

Data are expressed as the mean \pm standard deviation; values in the same row having different letters differ significantly $(p<0.05)$.

Mineral contents of seeds (Table 3) varied between both species, but potassium constituted the major mineral in both cases, ranging from $978.46 \mathrm{mg} / 100 \mathrm{~g}$ in $I$. hederacea to $1,236.51 \mathrm{mg} / 100 \mathrm{~g}$ in 
L. sativum. Zinc was found in the lowest quantity in I. hederacea $(4.0 \mathrm{mg} / 100 \mathrm{~g})$, while L. sativum had the lowest manganese content $(2.0 \mathrm{mg} / 100 \mathrm{~g})$ content. Both species contained good amounts of calcium, phosphorus and magnesium. Mineral content for L. sativum is in agreement with those reported earlier for L. sativum [22], while the metal content of I. hederacea has not been reported previously. The relatively high amount of sodium in I. hederacea seeds indicates that its high consumption might cause problems for hypertensive patients. Considering the different elements present in seeds of both plants, both plants have potential for providing essential nutrients for human and other animals, since the nutritional activity of any plant is usually related to the particular elements it contains [25].

Table 3. Mineral content (mg/100 g) of seeds.

\begin{tabular}{ccc}
\hline Metals & Ipomoea hederacea & Lepidium sativum \\
\hline Calcium & $317.41 \pm 1.72 \mathrm{~b}$ & $266.35 \pm 1.44 \mathrm{a}$ \\
Copper & $4.62 \pm 0.64 \mathrm{~b}$ & $5.73 \pm 2.11 \mathrm{a}$ \\
Iron & $9.85 \pm 1.02 \mathrm{a}$ & $8.31 \pm 0.36 \mathrm{a}$ \\
Magnesium & $179.14 \pm 1.23 \mathrm{~b}$ & $339.23 \pm 2.13 \mathrm{a}$ \\
Manganese & $6.37 \pm 0.68 \mathrm{a}$ & $2.00 \pm 1.08 \mathrm{~b}$ \\
Phosphorus & $596.19 \pm 2.36 \mathrm{a}$ & $608.63 \pm 1.39 \mathrm{a}$ \\
Potassium & $978.46 \pm 1.44 \mathrm{~b}$ & $1236.51 \pm 1.67 \mathrm{a}$ \\
Sodium & $106.32 \pm 1.33 \mathrm{a}$ & $19.65 \pm 0.98 \mathrm{~b}$ \\
Zinc & $4.01 \pm 0.69 \mathrm{~b}$ & $6.99 \pm 0.54 \mathrm{a}$ \\
Na:K & 0.11 & 0.01 \\
Ca:P & 0.53 & 0.43
\end{tabular}

Data are expressed as the mean \pm standard deviation; values in the same row having different letters differ significantly $(p<0.05)$.

Physico-chemical parameters provide important information regarding storage, structural stability and quality of seed oils. The physico-chemical properties of the investigated oils (Table 4) are in agreement with those reported earlier for L. sativum [26,27]. The color of an oil is an important feature which often determines the consumers' acceptability of the product. The oil color observed for L. sativum is dirty yellow, while that of I. hederacea is light yellow. Oil color is mainly due to the presence of some pigments like chlorophyll and carotenoids which are unintentionally co-extracted during the oil extraction process. The high refractive index values $(1.47 \pm 0.03$ to $1.47 \pm 0.08)$ are an indication of substantial unsaturation in these oils. The refractive index also provides useful information about the purity of oils. Each oil has certain range for this parameter and deviation of the data from the set specification may indicate adulteration of oil [28]. Like other parameters there is limited information on oil physico-chemical characteristics of $I$. hederacea seed oil however our results are comparable to some investigated parameters [29]. Oil composition (Table 5) showed a high content of triacylglycerols, i.e., $80.2 \pm 0.51$ and $90.00 \pm 0.62 \mathrm{~g} / 100 \mathrm{~g}$ for I. hederacea and L. sativum respectively. Hydrocarbons and waxes were observed to be present in the lowest amount in both oils. Seed oils can be separated into the various classes on the basis of their relative polarity by using various chromatographic methods, mostly by thin-layer chromatography (TLC). Although this technique is time-consuming, yet it is the most used to study oil classes. Free fatty acids are the products of 
hydrolysis, formed either due to chemical (due to presence of moisture) or lypolytic hydrolysis (due to presence of natural enzymes, especially lipases). Lower free fatty acid contents $(1.20 \pm 0.42$ to $0.58 \pm 0.35 \mathrm{~g} / 100 \mathrm{~g}$ for $I$. hederacea and L. sativum, respectively, indicate a low degree of hydrolysis and thus good oil quality. The low free fatty acid value of both oils also indicates that oils are rich in triglycerides which is a basic and desirable property of edible oils [30].

Table 4. Physico-chemical parameters of oils of I. hederacea and L. sativum.

\begin{tabular}{ccc}
\hline Parameter & Ipomoea hederacea & Lepidium sativum \\
\hline Color & Light yellow & Dirty Yellow \\
Refractive index & $1.47 \pm 0.03 \mathrm{a}$ & $1.47 \pm 0.08 \mathrm{a}$ \\
Specific gravity & $0.92 \pm 0.04 \mathrm{a}$ & $0.82 \pm 0.06 \mathrm{a}$ \\
Unsaponifiable matter & $1.73 \pm 0.11 \mathrm{a}$ & $0.57 \pm 0.02 \mathrm{~b}$ \\
Acid value & $2.98 \pm 0.08 \mathrm{a}$ & $1.04 \pm 0.05 \mathrm{~b}$ \\
Saponification value & $190.48 \pm 0.67 \mathrm{a}$ & $179.03 \pm 0.73 \mathrm{~b}$ \\
\hline
\end{tabular}

Data are expressed as the mean \pm standard deviation; values in the same row having different letters differ significantly $(p<0.05)$.

Table 5. Composition (\%) of oils of I. hederacea and L. sativum.

\begin{tabular}{ccc}
\hline Oil class & Ipomoea hederacea & Lepidium sativum \\
\hline Hydrocarbons + waxes & $0.40 \pm 0.23 \mathrm{a}$ & $0.30 \pm 0.04 \mathrm{a}$ \\
Steryl esters & $0.60 \pm 0.34 \mathrm{a}$ & $0.70 \pm 0.07 \mathrm{a}$ \\
Triacylglycerols & $80.20 \pm 0.51 \mathrm{~b}$ & $90.00 \pm 0.62 \mathrm{a}$ \\
Free fatty acid & $1.20 \pm 0.42 \mathrm{a}$ & $0.58 \pm 0.35 \mathrm{~b}$ \\
Diglycerols & $0.70 \pm 0.08 \mathrm{a}$ & $0.60 \pm 0.58 \mathrm{a}$ \\
Monoglycerols & $1.00 \pm 0.37 \mathrm{a}$ & $0.10 \pm 0.63 \mathrm{~b}$ \\
Polar lipids & $6.50 \pm 0.91 \mathrm{a}$ & $1.70 \pm 0.21 \mathrm{~b}$ \\
Phospholipids & $4.80 \pm 0.82 \mathrm{a}$ & $1.40 \pm 0.36 \mathrm{~b}$ \\
Unidentified & $4.60 \pm 0.57 \mathrm{a}$ & $4.63 \pm 0.67 \mathrm{a}$ \\
\hline
\end{tabular}

Data are expressed as the mean \pm standard deviation; values in the same row having different letters differ significantly $(p<0.05)$.

The fatty acid composition of I. hederacea seed oil is in agreement to that reported earlier [31]. Unsaturated fatty acids are found in higher amounts in both oils. Palmitic acid was observed as the most abundant saturated fatty acid, in amounts of $17.03 \pm 0.89$ and $10.3 \pm 0.12 \mathrm{~g} / 100 \mathrm{~g}$ for $I$. hederacea and L. sativum, respectively. Similarly palmitoleic acid was observed as being the least abundant unsaturated fatty acid, with values of $1.10 \pm 0.62$ and $0.70 \pm 0.30 \mathrm{~g} / 100 \mathrm{~g}$ for $I$. hederacea and L. sativum respectively. Fatty acid composition (Table 6) revealed high content of linoleic acid (52\%) in I. hederacea, while $\alpha$-linoleic acid (32.18\%) and oleic acid (30.5\%) were the most abundant fatty acids in the oil of L. sativum. Higher intake of oleic acid is associated with decreased risk of coronary heart disease caused by high cholesterol level in blood [32]. The fatty acid composition of the seed oils of these two plant species is interesting from the nutritional point of view for their higher contents of unsaturated fatty acids, especially $L$. sativum rich in $\omega-3$ fatty acids which are is beneficial for health. 
Table 6. Fatty acid profile (\%) of I. hederacea and L. sativum.

\begin{tabular}{ccc}
\hline Fatty acid & Ipomoea hederacea & Lepidium sativum \\
\hline Palmitic acid (16:0) & $17.03 \pm 0.89 \mathrm{a}$ & $10.30 \pm 0.12 \mathrm{~b}$ \\
Palmitoleic acid (16:1) & $1.10 \pm 0.62 \mathrm{a}$ & $0.70 \pm 0.30 \mathrm{~b}$ \\
Stearic acid (18:0) & $6.00 \pm 0.56 \mathrm{a}$ & $1.90 \pm 0.19 \mathrm{~b}$ \\
Oleic acid (18:1) & $19.50 \pm 0.37 \mathrm{~b}$ & $30.50 \pm 0.16 \mathrm{a}$ \\
Linoleic acid (18:2) & $52.09 \pm 0.48 \mathrm{a}$ & $8.60 \pm 0.38 \mathrm{~b}$ \\
Q-Linolenic acid (18:3) & $4.28 \pm 0.92 \mathrm{~b}$ & $32.18 \pm 0.59 \mathrm{a}$ \\
Arachidic acid (20:0) & - & $2.10 \pm 0.57$ \\
Eicosaenoic acid (20:1) & - & $13.40 \pm 0.66$ \\
\hline
\end{tabular}

Data are expressed as the mean \pm standard deviation; values in the same row having different letters differ significantly $(p<0.05)$.

Tocopherols are natural antioxidants that inhibit oil oxidation. Tocopherols act as biological scavengers of free radicals and could prevent diseases, besides possessing an important nutritional function for human beings as a source of vitamin E [33,34]. Total tocopherol contents observed were $33.10 \pm 0.56$ and $139.73 \pm 0.91 \mathrm{mg} / 100 \mathrm{~g}$ for $I$. hederace and $L$. sativum, respectively. $\gamma$-Tocopherol was found in the highest amount in seed oil of $I$. hederacea, while $\delta$-tocopherol was the most abundant in the seed oil of L. sativum (Table 7). High amounts of tocopherols can be interesting for the stabilization of fats and oils against oxidative deterioration and for applications in dietary, pharmaceutical, or biomedical products. Results presented are in agreement with those reported earlier [35-37].

Table 7. Tocopherol profile (mg/100g) of oils of I. hederacea and L. sativum.

\begin{tabular}{ccc}
\hline Tocopherol & Ipomoea hederacea & Lepidium sativum \\
\hline$\alpha$-Tocopherol & $0.50 \pm 0.21 \mathrm{~b}$ & $17.19 \pm 0.52 \mathrm{a}$ \\
$\beta$-Tocopherol & $1.60 \pm 0.21 \mathrm{a}$ & $0.10 \pm 0.08 \mathrm{~b}$ \\
$\gamma$-Tocopherol & $28.70 \pm 0.14 \mathrm{a}$ & $10.88 \pm 0.72 \mathrm{~b}$ \\
$\delta$-Tocopherol & $2.30 \pm 0.34 \mathrm{~b}$ & $111.56 \pm 0.37 \mathrm{a}$ \\
Total & $33.10 \pm 0.56 \mathrm{~b}$ & $139.73 \pm 0.91 \mathrm{a}$ \\
\hline
\end{tabular}

Data are expressed as the mean \pm standard deviation; values in the same row having different letters differ significantly $(p<0.05)$.

The samples were subjected to antioxidant capacity screening, using three different testing methods. The extracts of $I$. hederacea and $L$. sativum showed good antioxidant capacity, reducing different types of radicals (Table 8). In general, traditional spectrophotometric assays provide simple and fast screening methods to quantify total phenolic compounds in plant samples. However, due to the complexity of plant phenolics and different reactivity of phenols toward assay reagents, these results should be reinforced by the HPLC analysis, currently the most popular and reliable technique for analysis of phenolic compounds. Using this technique, coupled with mass spectrometer, tentative identification of phenolic compounds based on their mass spectra has been performed (Table 9). 
Table 8. Antioxidant activity of plant extract of I. hederacea and L. sativum.

\begin{tabular}{ccc}
\hline Antioxidant Assay & Ipomoea hederacea & Lepidium sativum \\
\hline Total phenol content $(\mathrm{mg}$ CAE/g $)$ & $14.33 \pm 0.09 \mathrm{~b}$ & $120.26 \pm 1.52 \mathrm{a}$ \\
TEAC $(\mu \mathrm{mol} \mathrm{TE} / \mathrm{g})$ & $93.57 \pm 2.42 \mathrm{~b}$ & $168.10 \pm 1.32 \mathrm{a}$ \\
FRAP $(\mu \mathrm{mol} \mathrm{Fe}++\mathrm{g})$ & $278.24 \pm 9.74 \mathrm{~b}$ & $1317.04 \pm 5.74 \mathrm{a}$ \\
TRAP $(\mu \mathrm{mol} \mathrm{TE} / \mathrm{g})$ & $69.02 \pm 2.92 \mathrm{~b}$ & $506.40 \pm 14.87 \mathrm{a}$ \\
\hline
\end{tabular}

Data are expressed as the mean \pm standard deviation; values in the same row having different letters differ significantly $(p<0.05)$.

Table 9. Tentative identification of phenolic compounds based on their mass spectral characteristics present in I. hederacea and L. sativum.

\begin{tabular}{ccccc}
\hline Compound & {$[\mathbf{M}-\mathbf{H}]^{-}(\boldsymbol{m} / \mathbf{z})$} & Qualifier ions $(\boldsymbol{m} / \mathbf{z})$ & I. hederacea & L. sativum \\
\hline Gallic acid & 169 & 125 & - & + \\
Ferulic acid & 193 & 134 & + & - \\
Protocatechuic acid & 153 & 109 & - & + \\
Coumaric acid & 163 & 119 & - & + \\
Caffeic acid & 179 & 135 & - & + \\
Coumaric acid-hexoside & 325 & 163,119 & + & + \\
Caffeic acid-hexoside & 341 & 179,135 & - & + \\
Ferulic acid-hexoside & 355 & 193,134 & + & + \\
Sinapic acid-hexoside & 385 & 223,149 & + & - \\
Vanillic acid-hexoside & 329 & 167 & - & + \\
Caffeoylquinic acid & 353 & $191,179,173,135$ & - & + \\
Coumaroylquinic acid & 337 & 191,173 & - & + \\
Kaemferol-hexoside & 447 & 285 & - & + \\
Quercetin-hexoside & 463 & 301 & - & + \\
Kaemferol-glucuronide & 461 & 285 & - & + \\
Quercetin & 301 & 151 & - & + \\
\hline
\end{tabular}

More phenolics have been identified in L. sativum than I. hederacea. In Figure 1, the chromatographic profile of some polyphenols identified in L. sativum is reported. At least three isomers of caffeoylquinic acid were identified in the seeds of L. sativum. These isomers had a negatively charged molecular ion ([M-H] $\left.]^{-}\right)$at $m / z 353$ and MS2 ions deriving from loss of the caffeoyl moiety and resulting ionization of free quinic acid $(\mathrm{m} / \mathrm{z} 191)$ and quinic acid with a loss of water molecule ( $m / z$ 173). Among chlorogenic acids, coumaroylquinic acids showed a $[\mathrm{M}-\mathrm{H}]^{-}$at $m / z 337$, and were characterized by the same fragmentation patterns of caffeoylquinic acids, involving the breakdown of hydroxycinnamate-quinic acid linkages. Moreover, coumaric acid was recovered in esterified form with hexose groups, with a $[\mathrm{M}-\mathrm{H}]^{-}$at $\mathrm{m} / \mathrm{z} 325$, that generated by tandem mass fragmentation the free coumaric acid after loss of a hexose moiety $(\mathrm{m} / \mathrm{z} 163)$ and further fragmentation of free hydroxycinnamic acid ( $\mathrm{m} / \mathrm{z} 119)$ (Figure 2). 
Figure 1. MRM chromatograms of caffeoylquinic acid. It is possible to note at least three isomers (at 13.81, 19.47 and $24.29 \mathrm{~min}$ ), identified through the loss and ionization quinic acid $(353>191)$ and $(353>173)$ derived from loss of $\mathrm{H}_{2} \mathrm{O}$ from formed quinic acid. MRM chromatograms of coumaroylquinic acid, identified through the loss and ionization quinic acid $(337>191)$ and $(337>173)$ derived from loss of $\mathrm{H}_{2} \mathrm{O}$ from formed quinic acid.
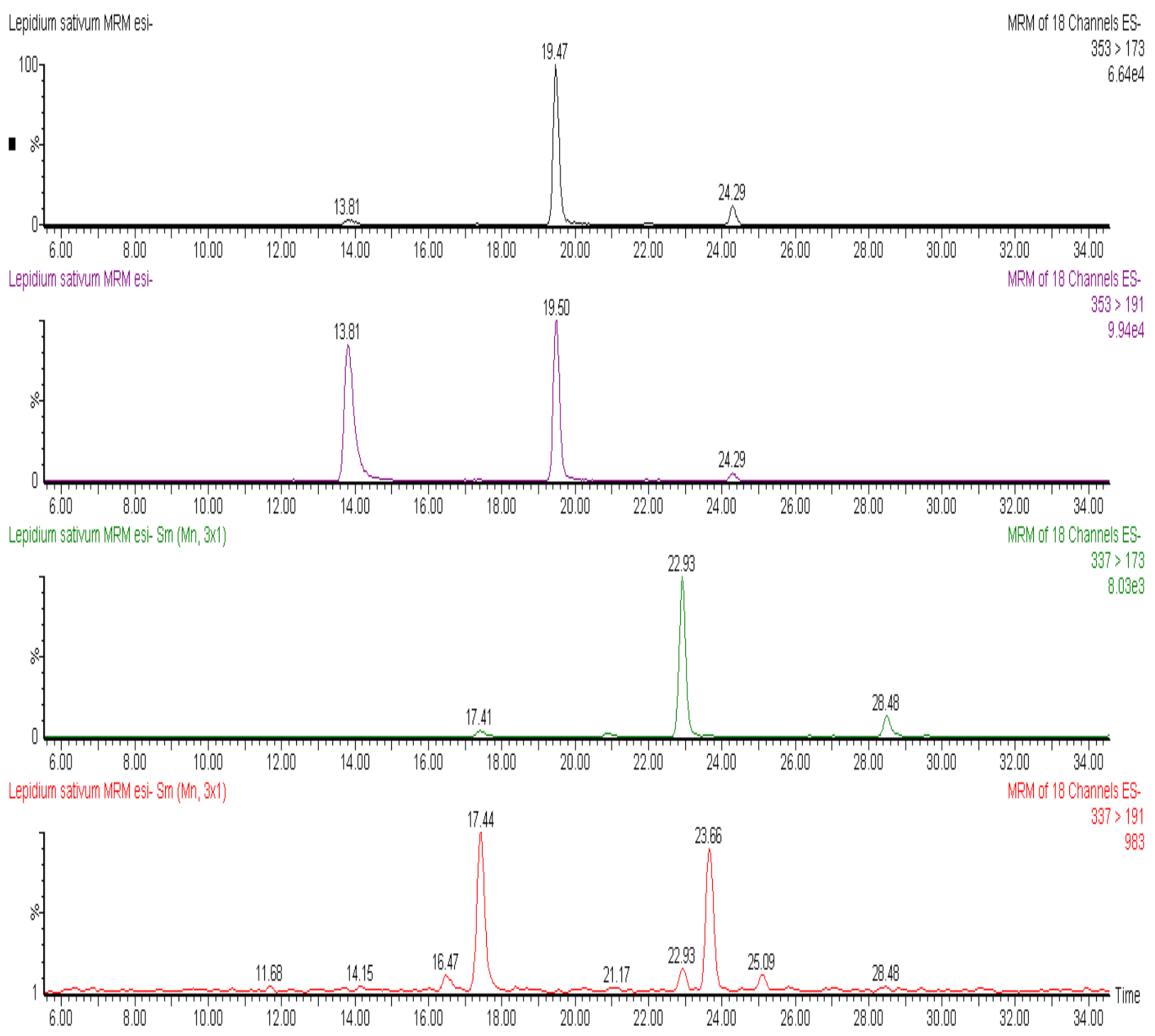

Besides phenolic acids, L. sativum contained several flavonoids, including two quercetin-hexosides that shared $[\mathrm{M}-\mathrm{H}]^{-}$at $m / z 463$, identified through the loss of sugar moieties (probably glucose and galactose units) and resultant ionization of quercetin at $\mathrm{m} / \mathrm{z} 301$, as reported in Figure 2. As for the phenolic profile of $I$. hederacea, only free ferulic acid and sinapic acid-hexosides were identified in this plant, while ferulic and coumaric acids were presented in esterified form with hexose groups, like in L. sativum.

Total antioxidant capacity, measured by three assays, and total phenolic content, measured using the Folin-Ciocalteu colorimetric method, of analyzed plant extracts are reported in Table 8. L. sativum seeds had a higher content of TPC (120.26 mg CAE/g) than Ipomea hederacea seeds and this is consistent with the higher number of phenolics identified in these seeds (Table 9). Few studies have evaluated the content of TPC in these plants. Compared to our results [38], analyzing the 
hydroalcoholic extracts of edible plants from Calabria (Italy), we found a lower content of TPC in L. sativum leaves, whereas Aziz-ur-Rehman et al. found a higher TPC value in I. hederacea extracted with different solvents and collected from the Kotli region in Pakistan [39]. Due to the higher content of TPC and total tocopherols, L. sativum showed higher values of total antioxidant capacity (TAC), regardless of the applied assay (Table 8), with respect to I. hederacea. TEAC and FRAP values of the analyzed L. sativum were high when compared to those found in Indian L. sativum seeds, which, accordingly, showed a lower content of TPC than that found in our sample [40]. Similarly, FRAP values of I. hederacea were higher than those reported by Aziz-ur-Rehman et al. [39]. It is well known that the antioxidant capacity and phenolic content of plants depend on several factors such as different genotype, growing condition, agronomic practices employed, season, maturity, post-harvest storage and processing conditions and solvent used for extraction. These factors may explain the differences found among our samples and those analyzed in previous studies.

Figure 2. MRM chromatograms of coumaric acid-hexosides. It is possible to note at least two isomers (at 15.28 and $17.71 \mathrm{~min}$ ), identified through the loss of hexose moiety (325>163) and further fragmentation of coumaric acid $(163>119)$. MRM chromatogram of quercetin-hexosides $(463>301)$, identified through the loss of sugar moiety and resultant ionization of quercetin.

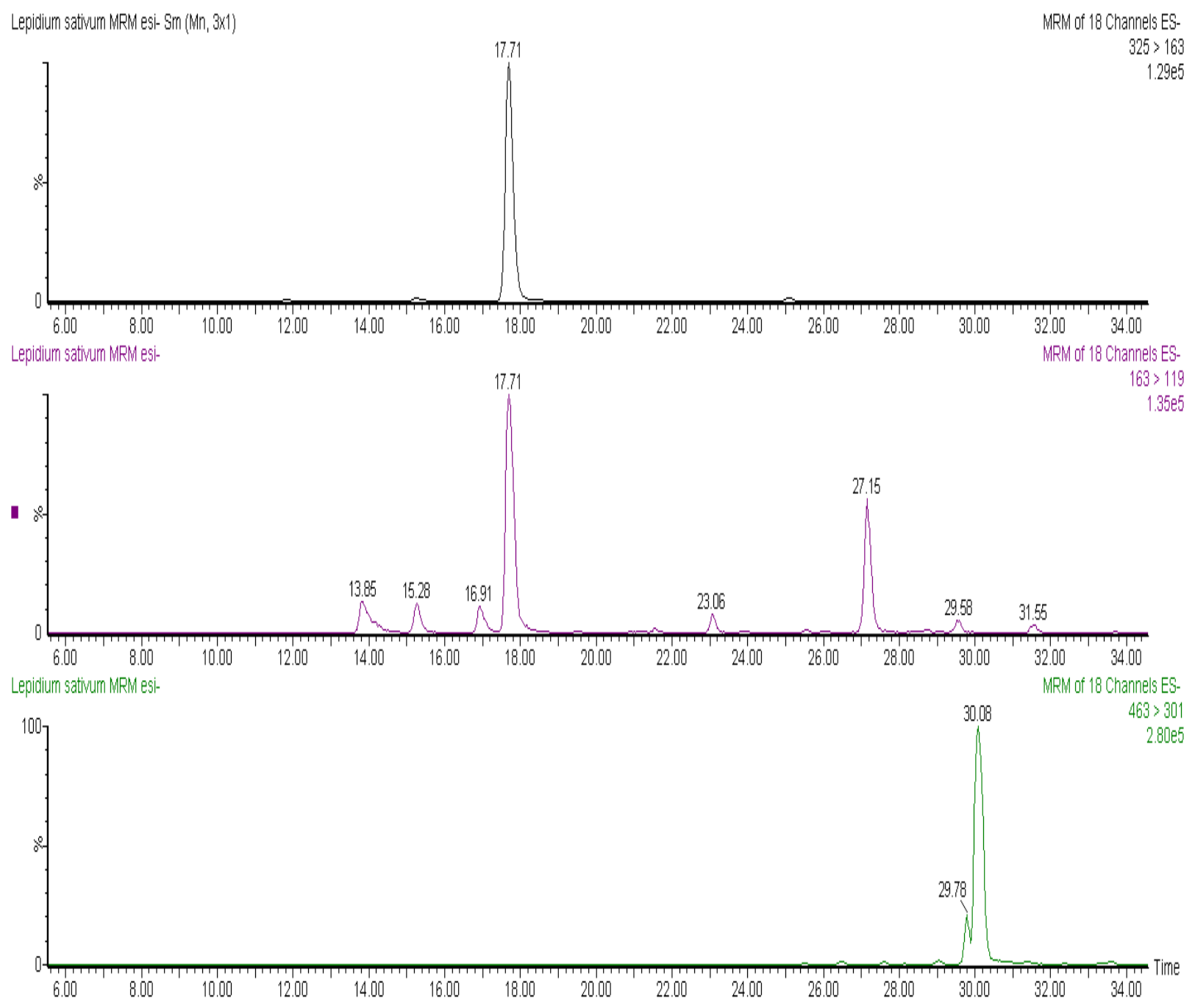




\section{Experimental}

\subsection{Plant Material}

Ipomoea hederacea and Lepidium sativum seeds were procured from the Department of Agronomy, Bahauddin Zakariya University, Multan, Pakistan. Seeds of both plants were stored in stainless-steel containers at $4{ }^{\circ} \mathrm{C}$ prior to analysis.

\subsection{Proximate Analysis}

Moisture, lipids, ash, protein, fibre and carbohydrates were determined according to the AOAC methods [41].

\subsection{Mineral Analysis}

The seeds were incinerated at $450{ }^{\circ} \mathrm{C}$ for $12 \mathrm{~h}$ in a muffle furnace and an acid digestate was prepared by oxidizing each sub-sample with a nitric/perchloric acid (2:1) mixture. Aliquots were used to estimate $\mathrm{Na}$ and $\mathrm{K}$ by flame photometry (Flame Photometer Model-EEL). The minerals, such as calcium, manganese, magnesium, zinc, iron and copper, were determined with an atomic absorption spectrophotometer (Perkin-Elmer Model 5000) while phosphorus was determined by the phosphovanado-molybdate (yellow) method [42]. The samples were quantified against standard solutions of known concentration that were analyzed concurrently [43].

\subsection{Amino Acid Analysis}

Samples $(300 \mathrm{mg})$ were hydrolyzed with $6 \mathrm{M} \mathrm{HCl}$ in an evacuated test tube for $24 \mathrm{~h}$ at $105{ }^{\circ} \mathrm{C}$. The dried residue was dissolved in citrate buffer ( $\mathrm{pH}$ 2.2) after flash evaporation. Aliquots were analyzed in an automatic amino acid analyzer (Hitachi Perkin-Elmer Model KLA 3B), using the buffer system described earlier [44]. Methionine and cystine were analysed separately after performic acid treatment and subsequent hydrolysis with $\mathrm{HCl}$. Tryptophan was determined after alkali $(\mathrm{NaOH})$ hydrolysis by the colorimetric method [45].

\subsection{Extraction of Oil and Physical Properties}

The seeds were ground to flour and were passed through a 60 -mesh sieve. The seed powder was extracted with a mixture of $n$-hexane/2-propanol $(3: 1, \mathrm{~V} / \mathrm{V})$ in a Soxhlet apparatus for $6 \mathrm{~h}$ [46]. The color of the oil was noted, at room temperature, by visual inspection. Determination of refractive index (RI), acid value, saponification value (SV) and unsaponifiable matter (UM) of the extracted oil was carried out by standard IUPAC methods for the analysis of oils [47].

\subsection{Oil Classes (\%)}

Oil samples were fractionated by a reported method [48] using silica gel, G 60 Merck type 5721 and $20 \mathrm{~cm} \times 20 \mathrm{~cm}$ glass plates with $0.25 \mathrm{~mm}$ thickness. The developing solvent system was $n$-hexane/ diethyl ether/ glacial acetic acid (80:20:2, V/V/V). The separated oil fractions were visualized by 
exposure to iodine vapor in a closed chamber after drying. All fractions were identified on thin layer plates by comparing their Rf values with those of known standards. For quantitative analysis, the different fractions were scanned by using Shimadzu TLC-Scanner (C-S-910). The area under each peak was measured by the triangulation method [33]. The percentage of each component was calculated with regard to the total area by a reported procedure [49] as follows:

$\%$ Component $=($ Area of each peak $) /($ Total peaks area $) \times 100$

\subsection{Fatty Acid (FA) Composition}

Fatty acid methyl esters (FAMEs) were prepared according to the standard IUPAC method 2.301 [46] and analyzed on a Shimadzu 17-A gas chromatograph equipped with a flame ionization detector (FID). Separation was done on a SP 2330 capillary column $(30 \mathrm{~m} \times 0.32 \mathrm{~mm} \times 0.25 \mu \mathrm{m}$; Supelco, Bellefonte, PA, USA). Nitrogen was used as a carrier gas at a flow rate of $3.0 \mathrm{~mL} / \mathrm{min}$. Column temperature was programmed from 180 to $220{ }^{\circ} \mathrm{C}$ at the rate of $3{ }^{\circ} \mathrm{C} / \mathrm{min}$. Initial and final temperatures were held for 2 and $10 \mathrm{~min}$, respectively. Injector and detector were kept at 230 and $250{ }^{\circ} \mathrm{C}$, respectively. A sample volume of $1.0 \mu \mathrm{L}$ was injected with the split ratio of 1:75. FAMEs were identified by comparing their relative and absolute retention times to those of authentic standards. The quantification was done by a Chromatography Station for Windows (CSW32) data handling software (Data Apex Ltd. CZ-158 00 Prague, Czech Republic). The fatty acid composition was reported as a relative percentage of the total peak area.

\subsection{Tocopherol Contents}

For determination of tocopherols, $250 \mathrm{mg}$ of oil (obtained as mentioned in Section 3.5) was dissolved in $n$-heptane $(25 \mathrm{~mL})$ and used for the HPLC analysis which was conducted using a Merck-Hitachi low-pressure gradient system, fitted with an L-6000 pump, a Merck-Hitachi F-1000 Fluorescence Spectrophotometer (detector wavelengths for excitation $295 \mathrm{~nm}$, for emission $330 \mathrm{~nm}$ ) and a D-2500 integration system; samples $(20 \mu \mathrm{L})$ were injected by a Merck 655-A40 Autosampler onto a diol phase HPLC column $25 \mathrm{~cm} \times 4.6 \mathrm{~mm}$ ID (Merck, Darmstadt, Germany) using a flow rate of $1.3 \mathrm{~mL} / \mathrm{min}$. The mobile phase used was $n$-heptane/tert-butyl methyl ether $(99+1, \mathrm{v} / \mathrm{v})$ [50].

\subsection{Sample Preparation for Antioxidant Assays}

The seeds were ground to flour with an IKA® All Basic mill (IKA Works Inc., Wilmington, NC, USA) and passed through a 60-mesh sieve. The flour was macerated with aqueous methanolic mixture (3 Litre, 80:20; v/v), at room temperature for fifteen days with occasional shaking. The process was repeated three times with same quantity of solvent mixture. The extracts obtained were combined, filtered through filter paper under vacuum and concentrated under reduced pressure on a rotary evaporator (model Q-344B-Quimis, Sao Paulo, Brazil) using a warm water bath (model Q-214M2-Quimis) to obtain a thick gummy mass, which was further dried in a dessicator and stored in air-tight vial till further use . 


\subsubsection{Total Phenolic Content}

A weighed amount of extract sample (between 50 and $130 \mathrm{mg}$ depending on the sample) was dissolved with acidified methanol $\left(10 \mathrm{~mL}, 1 \%\right.$ formic acid). The extracts were kept at $-20{ }^{\circ} \mathrm{C}$ at dark prior to the analysis. The content of phenolic compounds was determined using the Folin-Ciocalteu method; based on the reduction of phosphotungstate-phosphomolybdate complex by phenolics to a blue reaction product that absorbance was measured at $760 \mathrm{~nm}$ [51]. The data were calculated according to standard curve of catechin $(0.01-0.20 \mathrm{mg} / \mathrm{mL})$, and were expressed as $\mathrm{mg}$ of catechin equivalents $(\mathrm{CE})$ per gram of extract.

\subsubsection{HPLC-ESI-MS/MS Analysis of Phenolic Compounds}

Phenolic compounds were analysed using a Water 2695 Alliance separation module equipped with a Micromass Quattro Micro API mass spectrometer fitted with an electrospray interface (ESI) (Waters, Milford, MA, USA). A preliminary investigation on phenolic profiles of selected plants was carried out by means of MS scan analysis, operating in negative ion mode from 100 to 1000 mass-to-charge ratio $(\mathrm{m} / \mathrm{z})$. Then, different Multiple Reaction Monitoring (MRM) methods were developed for all sample types, based on the obtained MS scan data. Separations were performed using a Waters Atlantis dC18 $3 \mu \mathrm{m}(2.1 \times 150 \mathrm{~mm})$ reverse phase column (Waters), with the mobile phase, pumped at a flow rate of $0.17 \mathrm{~mL} / \mathrm{min}$. The mobile phase was a $30-\mathrm{min}$ linear gradient of 5 to $30 \%$ acetonitrile in $1 \%$ aqueous formic acid. The ESI source worked in negative ionisation mode. Source temperature was $120^{\circ} \mathrm{C}$, desolvation temperature was $350{ }^{\circ} \mathrm{C}$, capillary voltage was $2.8 \mathrm{kV}$, cone voltage was $35 \mathrm{~V}$, desolvation gas (N2) $750 \mathrm{~L} / \mathrm{h}$, cone gas (N2) $50 \mathrm{~L} / \mathrm{h}$. The collision energy for MS/MS identifications was set at $30 \mathrm{eV}$, and the collision gas used was argon.

\subsubsection{Total Antioxidant Capacity}

Plant extracts were analysed for their antioxidant capacity by three different assays described before: 2,2'-azino-bis(3-ethylbenzthiazoline-6-sulphonic acid) radical-scavenging activity (ABTS method), [52], ferric reducing antioxidant power (FRAP) assay, [53], and total radical-trapping antioxidant parameter (TRAP) assay [54]. The TEAC and TRAP values were expressed as micromoles of Trolox per $g$ of plant extract, FRAP values were expressed as micromoles of $\mathrm{Fe}^{2+}$ equivalents per $\mathrm{g}$ of plant extract.

\subsection{Statistical Analysis}

All analyses were performed in triplicate and values expressed as the mean \pm standard deviation. Data analysis was carried out using the analysis of variance and MSTATC statistical computer package [55].

\section{Conclusions}

The content of biologically active compounds, as well as the antioxidant capacity of $I$. hederacea and L. sativum have been investigated in this study. Our findings indicate that seeds of both plants are 
a good source of amino acids, minerals, fatty acids and have the ability to act in vitro as antioxidants. This may be due to their high content of phenolic compounds. These plants may warrant further investigation for their potential preventive effects towards chronic diseases and should be further investigated as interesting ingredients for new functional food formulations.

\section{References}

1. Facciola, S. Cornucopia-A Source Book of Edible Plants; Kampong Publications: Vista, CA, USA, 1990.

2. Usher, G.A. Dictionary of Plants Used by Man; Constable and Company Ltd.: London, UK, 1974.

3. Thompson, R. The Gardener's Assistant, a Practical and Scientific Exposition of the Art of Gardening in All Its Branches; The Gresham Publishing Co.: London, UK, 1878.

4. Datta, P.K.; Diwakar, B.K.; Viswanatha, S.; Murthy, K.N.; Naidu, K.A. Safety evaluation studies on Garden cress (Lepidium sativum L.) seeds in Wistar rats. Int. J. App. Res. Nat. Prod. 2011, 4, 37-43.

5. Manohar, D.; Viswanatha, G.L.; Nagesh, S.; Jain, V.; Shivaprasad, H.N. Ethnopharmacology of Lepidium Sativum Linn (Brassicaceae): A review. Int. J. Phyt. Res. 2012, 2, 1-7.

6. Linkies, A.; Leubner-Metzger, G. Beyond gibberellins and abscisic acid: How ethylene and jasmonates control seed germination. Plant Cell Rep. 2012, 31, 253-270.

7. Weitbrecht, K.; Müller, K.; Leubner-Metzger, G. First off the mark: Early seed germination. J. Exp. Bot. 2011, 62, 3289-3309.

8. Nasir, E.; Ali, S.I. Flora of West Pakistan; Shamim Printing Press: Karachi, Pakistan, 1979.

9. Franco, I.J.; Fontana, V.L. Ervas and Plantas: A Medicina Dos Simples; Livraria Vida Ltda: Erechim, Brazil, 1997; p. 177.

10. Joshi, S.G. Medicinal Plants; Oxford and IBH Publishing Co. Ltd: Jan Paths, New Delhi, India, 2000.

11. Zia-Ul-Haq, M.; Ahmad, M.; Iqbal, S. Characterization and compositional studies of oil from seeds of desi chickpea (Cicer arietinum L.) cultivars grown in Pakistan. J. Am. Oil Chem. Soc. 2007, 84, 1143-1148.

12. Zia-Ul-Haq, M.; Iqbal, S.; Ahmad, S.; Bhanger, M.I.; Wiczkowsk, W.; Amarowicz, R. Antioxidant potential of desi chickpea varieties commonly consumed in Pakistan. J. Food Lipids 2008, 15, 26-342.

13. Zia-Ul-Haq, M.; Ahmad, S.; Chiavaro, E.; Mehjabeen Ahmed, S. Studies of oil from cowpea (Vigna unguiculata (L) walp.) cultivars commonly grown in Pakistan. Pak. J. Bot. 2010, 42, 1333-1341.

14. Zia-Ul-Haq, M.; Ahmad, S.; Shad, M.A.; Iqbal, S.; Qayum, M.; Ahmad, A.; Luthria, D.L.; Amarowicz, R. Compositional studies of some of lentil cultivars commonly consumed in Pakistan. Pak. J. Bot. 2011, 43, 1563-1567.

15. Zia-Ul-Haq, M.; Ahmad, S.; Iqbal, S.; Luthria, D.L.; Amarowicz, R. Antioxidant potential of lentil cultivars commonly consumed in Pakistan. Oxid. Comm. 2011, 34, 819-831.

16. Zia-Ul-Haq, M.; Cavar, S.; Qayum,M.; Imran, I.; DeFeo,V. Compositional studies, antioxidant and antidiabetic activities of Capparis decidua (Forsk.) Edgew. Int. J. Mol. Sci. 2011, 12, 8846-8861. 
17. Zia-Ul-Haq, M.; Shahid, S.A.; Ahmad, S.; Qayum, M.; Khan, I. Antioxidant potential of various parts of Ferula assafoetida L. J. Med. Plant. Res. 2012, 6, 3254-3258.

18. Rizwan, K.; Zubair, M.; Rasool, N.; Riaz, M.; Zia-Ul-Haq, M.; DeFeo, V. Chemical and biological study of Agave attenuata. Int. J. Mol. Sci. 2012, 13, 6440-6451.

19. Marangoni, A.; Alli, I. Composition of the seeds and pods of the tree legume Prosopis Juliflora. J. Sci. Food Agric. 1988, 44, 99-110.

20. Spinner, G.P.; Bishop, J.S. Chemical analysis of some wildlife foods in Connecticut. J. Wild Life Manag. 1950, 14, 175-180.

21. Schroeder, M.; Deli, J.; Schall, E.D.; Warren, G.F. Seed composition of 66 weed and crop species. Weed Sci. 1974, 22, 345-348.

22. Moser, B.R.; Shah, S.N.; Winkler-Moser, J.K.; Vaughn, S.F.; Evangelista, R.L. Composition and physical properties of cress (Lepidium sativum L.) and field pennycress (Thlaspi arvense L.) oils. Ind. Crop Prod. 2009, 30, 199-205.

23. Frias, J.; Gulewicz, P.; Martinez-Villaluenga, C.; Pinas, E.; Piskula, M.K.; Kozlowska, H.; Ciska, E.; Gulewicz, K.; Vidal-Valverde, K.V. Changes in nutritional value and cytotoxicity of garden cress germinated with different selenium solutions. J. Agric. Food Chem. 2010, 58, 2331-2336.

24. Gokavi, S.S.; Nagappa, G.M.; Guo, M. Chemical composition of garden cress (Lepidium sativum) seeds and its fractions and use of bran as a functional ingredient. Plant Foods Hum. Nutr. 2004, 59, 105-111.

25. Sofowora, A. Medicinal Plants and Traditional Medicine in Africa; Spectrum Books Ltd.: Ibadan, Nigeria, 1993.

26. Ritesh, P.; Sudeep, K.; Reneesh, J.; Sudhish, R.; Alok, S.; Sumeet, D. Quantitative estimation of fixed oil obtained from seeds of Lepidium sativum Linn. Int. J. Chem. Anal. Sci. 2010, 1, 6-9.

27. Diwakar, B.T.; Dutta, P.K.; Lokesh, B.R.; Naidu, K.A. Physicochemical properties of garden cress (Lepidium sativum L.) seed oil. J. Am. Oil Chem. Soc. 2009, 5, 539-548.

28. Arya, S.S.; Ramanujam, S.; Vijayaraghavan, P.K. Refractive index as an objective method for evaluation of rancidity in edible oils and fats. J. Am. Oil Chem. Soc. 1969, 46, 28-30.

29. Yashpal, K.; Sikhibhushan, D. Chemical examination of the fixed oil from the seeds of Ipomoea hederacea. Ind. Soap J. 1947, 13, 77-80.

30. Shahnaz, H.; Hifza, A.; Bushra, K.; Khan, J.I. Lipid studies of Cuminum cyminum fixed oil. Pak. J. Bot. 2004, 36, 395-401.

31. Genest, K.; Sahasrabudhe, M.R. Alkaloids and lipids of Ipomoea, Rivea and Convolvulus and their application to chemotaxonomy. Econom. Bot. 1966, 20, 416-428.

32. Corbett, P. It is time for an oil change, Opportunities for high oleic vegetables oils. Inform 2003, $14,480-481$.

33. Brigelius-Flohe, R.; Kelly, F.J.; Salonem, J.T.; Neuzil, J.; Zingg, J.M.; Azzi, A. The European perspective on vitamin E: Current knowledge and future research. Am. J. Clin. Nutr. 2002, 76, 703-716.

34. Monahan, F.J.; Gray, J.I.; Asghar, A.; Haug, A.; Shi, B.; Bukley, D.J. Effect of dietary lipid and Vitamin E supplementation on free radical production and lipid oxidation in porcine muscle microsomal fractions. Food Chem. 1993, 46, 1-6. 
35. Imbs, A.B.; Pham, L.Q. Lipid composition of ten edible seed species from North Vietnam. J. Am. Oil Chem. Soc. 1995, 72, 957-961.

36. Mariod, A.; Matthaus, B. Physico-chemical properties, Fatty acid and tocopherol composition of oils from some Sudanese oil bearing sources. Grasas y Aceit. 2008, 59, 321-326.

37. Sharma, S.; Agarwal, N. Nourshing and healing powers of garden cress (Lepidium sativum Linn.): A review. Ind. J. Nat. Prod. Res. 2011, 2, 292-297.

38. Conforti, F.; Sosa, S.; Marrelli, M.; Menichini, F.; Statti, G.A.; Uzunov, D.; Tubaro, A.; Menichini, F. The protective ability of Mediterranean dietary plants against the oxidative damage: The role of radical oxygen species in inflammation and the polyphenol, flavonoid and sterol contents. Food Chem. 2009, 112, 587-594.

39. Aziz-ur-Rehman; Abbas, A.; Riaza, T.; Ahmad, S.; Zaman, S.; Abbasi, M.A.; Siddiqui, S.Z.; Ajaib, M. Ipomoea hederacea: An imperative source for natural antioxidants. Asian J. Pharm. Biol. Res. 2011, 1, 534-541.

40. Surveswaran, S.; Cai, Y.Z.; Corke, H.; Sun, M. Systematic evaluation of natural phenolic antioxidants from 133 Indian medicinal plants. Food Chem. 2007, 102, 938-953.

41. Association of Official Analytical Chemists (AOAC). Official Methods of Analysis of the Association of Official Analytical Chemists, 14th ed.; AOAC: Washington, DC, USA, 1990.

42. Zia-Ul-Haq, M.; Iqbal, S.; Shakkel, A.; Imran, M.; Niaz, A.; Bhanger, M.I. Nutritional and compositional study of Desi chickpea (Cicer arietinum L.) cultivars grown in Punjab, Pakistan. Food Chem. 2007, 105, 1357-1363.

43. Khalil, I.A.; Durani, F.R. Haulm and Hull of peas as a protein source in animal feed. Sarhad J. Agric. 1990, 6, 219-225.

44. Zarkdas, C.G.; Yu, Z.; Voldeng, H.K.; Minero-Amador, A. Assessment of the protein quality of new high protein Soybean cultivar by amino acid analysis. J. Agri. Food Chem. 1993, 41, 616-626.

45. Zia-Ul-Haq, M.; Iqbal, S.; Ahmad, M. Characteristics of oil from seeds of 4 mungbean (Vigna radiata (L.) wilczek cultivars grown in Pakistan. J. Am. Oil Chem. Soc. 2008, 85, 851-856.

46. Dieffenbacher, A.; Pocklington, W.D. Standard Methods for the Analysis of Oils Fats and Derivatives International Union of Pure and Applied Chemistry; Blackwell Scientific Publications: Oxford, UK, 1987.

47. Malins, D.C.; Mangold, H.K. Fractionation of fats, oils and waxes on thin-layer of silicic acid. J. Am. Oil Chem. Soc. 1960, 37, 383-385.

48. Kates, M. Techniques of Lipidology Isolation Analysis and Identification of Lipids; North-Holland Publication Co.: Amsterdam, The Netherlands, 1972.

49. El-Sayed, A.A.; El-Fishawy, F.A.; El-Geddawy, M.A.; Kurz, T.; El-Rify, M.N. The changes in the lipid composition of mung bean seeds as affected by processing methods. Int. J. Food Eng. 2007, 3, 1-10.

50. Balz, M.; Shulte, E.; Their, H.P. Trennung von Tocopherol und Tocotrienolendurch HPLC. Fat Sci. Technol. 1992, 94, 209-213.

51. Singleton, C.L.; Rossi, J.A. Colorimetry of total phenolics with phosphomolybdic-phosphotungstic acid reagents. Am. J. Enol. Viticult. 1965, 16, 144-158. 
52. Pellegrini, N.; Serafini, M.; Colombi, B.; Del-Rio, D.; Salvatore, S.; Bianchi, M.; Brighenti, F. Total antioxidant capacity of plant foods, beverages and oils consumed in Italy assessed by three different in vitro assays. J. Nutr. 2003, 133, 2812-2819.

53. Benzie, I.F.F.; Strain, J.J. Ferric reducing/antioxidant power assay: Direct measure of total antioxidant activity of biological fluids and modified version for simultaneous measurement of total antioxidant power and ascorbic acid concentration. Methods Enzymol. 1999, 299, 15-27.

54. Ghiselli, A.; Serafini, M.; Maiani, G.; Azzini, E.; Ferro-Luzzi, A.A. Fluorescence-based method for measuring total plasma antioxidant capability. Free Radic. Biol. Med. 1995, 18, 29-36.

55. Freed, R.; Eisensmith, S.P.; Goetz, S.; Reicosky, D.; Smail, V.W.; Welberg, P. User's Guide to MSTAT-C; Michigan State University: East Langing, MI, USA, 1991.

Sample Availability: Samples of the compounds are available from the authors.

(C) 2012 by the authors; licensee MDPI, Basel, Switzerland. This article is an open access article distributed under the terms and conditions of the Creative Commons Attribution license (http://creativecommons.org/licenses/by/3.0/). 